\title{
SPECTROPHOTOMETRIC DETERMINATION OF RUTHENIUM UTILIZING ITS CATALYTIC ACTIVITY ON OXIDATION OF HEXACYAN OFERRATE(II) BY PERIODATE ION IN WATER SAM PLES
}

\author{
Abhishek Srivastava ${ }^{1,}{ }^{*}$, Vivek Sharma ${ }^{1}$, Anjali Prajapati ${ }^{1}$, Neetu Srivastava ${ }^{2}$, R. M. Naik ${ }^{3}$
}

https://doi.org/10.23939/chcht13.03.275

\begin{abstract}
The catalytic effect of ruthenium chloride on the outer sphere electron transfer of hexacyanoferrate(II) by periodate ion in aqueous alkaline medium has been effectively employed to determine ruthenium(III) at micro level. The optimum reaction condition has been established and fixed time procedure is adopted. A linear relationship between changes in absorbance and added $\mathrm{Ru}(\mathrm{III})$ concentration has been utilized for the trace level determination of $\mathrm{Ru}(\mathrm{III})$. The results reveal that the addition of interfering ions (up to 71 times higher concentration of $\mathrm{Ru}$ ) does not have significant effect on the catalytic activity of $\mathrm{Ru}(\mathrm{III})$ on oxidation of hexacyanoferrate(II) by periodate ion. Polyaminocarboxylates (HEDTA, EDTA and IDA) suppress its catalytic power to maximum, if tolerance limit is more than 14.29 times. Due to the reproducibility, stability and selectivity, this method can also be quantitatively applied in different types of water samples for determination of ruthenium(III) at micro level.
\end{abstract}

Keywords: kinetics, mechanism, hexacyanoferrate(II), periodate, ruthenium(III).

\section{Introduction}

Ruthenium, a noble metal, is found in crustal materials at very low concentration (few ppb) [1], whereas meteorites and chondrite contain much higher percentage of ruthenium [2]. However, ruthenium compounds are highly toxic and carcinogenic, different studies have been reported for materials containing ruthenium complexes in electronic, electrochemical and electrical industries [1, 2]. The

\footnotetext{
${ }^{1}$ Department of Chemistry, G.L.A. University, Mathura, U.P., India

${ }^{2}$ Department of Chemistry, D.D.U. Gorakhpur University, Gorakhpur, 273001, U.P., India

${ }^{3}$ Department of Chemistry, Lucknow University, Lucknow, 226007, U.P. India

*aabhichem@gla.ac.in

(C) Srivastava A., Sharma V., Prajapati A., Srivastava N., Naik R. M., 2019
}

complexes of ruthenium have found applications in pharmaceutical industries in the detection and determination of protein, antibiotic, chloramphenicol, and cefprozil [3-5]. Ruthenium along with its complexes exhibits excellent catalytic property in both alkaline and acidic medium for the reactions having environmental and commercial applications [6-18]. To fight against the deadly disease of cancer a number of ruthenium bearing complexes have been prepared and their antitumor properties are tested [19-21]. The life span of hosts bearing tumor increases by the intake of certain ruthenium compounds in spite of low cytotoxicity of ruthenium agents. Due to high catalytic activity of ruthenium, alloys of ruthenium are used as catalyst in fuel cells. Pt-Ru bimetallic alloy show the highest activity for the methanol oxidation reaction in methanol fuel cells [22]. Nanoparticles of $\mathrm{Ru}-\mathrm{Pt}$ have also been used as an effective catalyst for carbon monoxide - tolerant fuel cell [23]. Thus, the potential application of ruthenium and its complexes in various areas, especially in pharmacology [24] and metallurgy [25] has made a challenge to develop a rapid, selective, simple and inexpensive method for the determination of ruthenium in different type of samples at trace level. The catalytic and inhibition properties have been extensively used for the growth and development of analytical methods for the trace level determination of different elements and compounds. The processes for the ruthenium determination viz. spectrophotometry, cyclic voltametry, atomic absorption spectrophotometry, mass spectrometry, HPLC, atomic absorption spectrometry, and X-ray fluorescence, have been used by investigators. Despite of good sensitivity and selectivity most of these methods are complicated, time consuming and require expensive chemicals. Therefore, the catalytic kinetic methods (CKMs) employing spectrophotometric monitoring (SPM) under pseudo condition still remain a popular method for achieving ruthenium(III) estimation at trace level [26-38]. A comparison of known CKMs along with reaction condition, types of sample and dynamic range of detection (DRD) are summarized in Table 1 [28, 29, 32-38]. 
A comparative study of determination of ruthenium(III) involving different reactions

\begin{tabular}{|c|c|c|c|c|}
\hline Major reactants & $\begin{array}{c}\text { D.R.D. }(\chi \mathrm{d}) \\
\mathrm{ng} \cdot \mathrm{ml}^{-1}\end{array}$ & $\begin{array}{l}\text { Methods used and reaction } \\
\text { conditions }\end{array}$ & Samples used & $\begin{array}{l}\text { Ref. } \\
\text { No. }\end{array}$ \\
\hline $\begin{array}{l}\text { Thymol blue and potassium } \\
\text { bromate }\end{array}$ & 1 to 25 & $\begin{array}{c}\text { CKM, SPM, } \lambda \max 544 \mathrm{~nm}, \\
\text { temp. } 308 \mathrm{~K}\end{array}$ & Synthetic samples & 32 \\
\hline Tren and hexacyanoferrate(III) & 10.11 to 252.67 & $\begin{array}{l}\text { CKM, SPM, } \lambda \max 420 \mathrm{~nm} \text {, } \\
\text { temp. } 318 \mathrm{~K} \text {, time } 10 \mathrm{~min}\end{array}$ & Water samples & 28 \\
\hline Benzylamine and $\left[\mathrm{Fe}(\mathrm{CN})_{6}\right]^{3-}$ & 10 to $121(6.90)$ & $\begin{array}{l}\text { CKM, SPM, } \lambda \max : 420 \mathrm{~nm} \text {, } \\
\text { temp. } 308 \mathrm{~K} \text {, time } 5 \mathrm{~min}\end{array}$ & Synthetic samples & 34 \\
\hline Phenosafranine and $\mathrm{NaIO}_{4}$ & Nanogram range & CKM, SPM, $\lambda \max 520 \mathrm{~nm}$ & Synthetic water samples & 36 \\
\hline L-Phenylalanine and $\mathrm{KMnO}_{4}$ & $\begin{array}{c}0.101 \text { to } 2.526 \\
(0.08)\end{array}$ & $\begin{array}{c}\mathrm{CKM}, \mathrm{SPM}, \lambda \max 526 \mathrm{~nm}, \\
\text { temp. } 318 \mathrm{~K} \text {, time } 5 \mathrm{~min}\end{array}$ & $\begin{array}{c}\text { Tap water, synthetic } \\
\text { mixtures }\end{array}$ & 29 \\
\hline $\mathrm{Ce}(\mathrm{IV})$ and $\mathrm{As}(\mathrm{III})$ & 0.45 to $9.00(0.08)$ & $\begin{array}{l}\text { CKM, SPM, } \lambda \max 625 \mathrm{~nm}, \\
\text { PC-ANN used }\end{array}$ & Synthetic samples & 37 \\
\hline Hematoxylin and $\mathrm{H}_{2} \mathrm{O}_{2}$ & 5 to 120 & $\begin{array}{c}\text { CKM, SPM, } \lambda \max 440 \mathrm{~nm}, \\
\text { temp. } 308 \mathrm{~K}\end{array}$ & Synthetic mixtures & 35 \\
\hline Acridine orange and chlorite & 1 to 10 & $\begin{array}{l}\text { CKM, SPM, } \lambda \max 490 \mathrm{~nm}, \\
\text { temp. } 298 \mathrm{~K} \text {, time } 5 \mathrm{~min}\end{array}$ & Synthetic water samples & 35 \\
\hline $\begin{array}{l}\text { Safranin } \mathrm{O} \text { and potassium } \\
\text { metaperiodate }\end{array}$ & $\begin{array}{l}0.80 \text { to100.0 } \\
(0.25)\end{array}$ & $\begin{array}{l}\text { CKM, SPM, } \lambda \max 521 \mathrm{~nm} \text {, } \\
\text { temp. } 308 \mathrm{~K} \text {, time } 5 \mathrm{~min}\end{array}$ & Synthetic water samples & 33 \\
\hline
\end{tabular}

In order to extend our efforts for development of CKMs for the determination of ruthenium(III) [28-29], the present study proposed a new, rapid, selective, sensitive, and less expensive method to determine $\mathrm{Ru}(\mathrm{III})$ by applying its catalytic property on oxidation of hexacyanoferrate(II) by periodate ion in highly basic condition. The proposed method permits to determine the $[\mathrm{Ru}(\mathrm{III})]$ down to $10 \mathrm{ng} \cdot \mathrm{ml}^{-1}$ with very good accuracy and reproducibility. The minute amount of ruthenium is also added in certain areas of rivers, lakes and oceans as industrial wastes. In the present study we have developed a selective $\mathrm{CKM}$ for $\mathrm{Ru}(\mathrm{III})$ determination in water samples.

\section{Experimental}

\subsection{Reagents}

Analytical grade chemicals and double distilled water were used throughout the investigation. Potassium hexacyanoferrate(II) (Sigma) was used as such for the preparation of stock solution and kept in dark colored container to prevent photo-degradation. The $1.0 \mathrm{M}$ solution of sodium metaperiodate (Merck) was prepared, to prevent decomposition it was always wrapped with aluminium foil. Calculated amount of ruthenium(III) chloride (Alfa) was used for the preparation of its stock solution $\left(100 \mu \mathrm{g} \cdot \mathrm{ml}^{-1}\right)$ in $0.5 \mathrm{M} \mathrm{HCl}$. The potassium iodide (S. D. Fine) solution was used to check the possible oxidation of ruthenium(III) in hydrochloric acid. Sodium chloride (Merck) solution was used to fix ionic strength $(0.1 \mathrm{M})$ of reaction mixture. $\mathrm{pH}$ of the reactants were fixed separately at $9.50 \pm 0.02$ using sodium hydroxide and perchloric acid. Standardization of $\mathrm{pH}$ meter was done by standard BDH buffers.

\subsection{Apparatus}

The progress of catalytic reaction was examined using Sisco single beam visible spectrophotometer, model GIGI-110 equipped with self designed thermostated cell chamber. The $\mathrm{pH}$ was maintained by Elico LI-120 digital $\mathrm{pH}$ meter. The glassware was cleaned thoroughly with detergent, rinsed with dilute EDTA, dipped in $10 \% \mathrm{HNO}_{3}$ for minimum $10 \mathrm{~min}$ and finally washed thoroughly with double distilled water. The spectrophotometer cuvettes were cleaned by soaking in $15 \% \mathrm{HNO}_{3}$ to discharge ruthenium traces adsorbed on cell walls.

\subsection{Procedure}

Except the $\mathrm{Ru}(\mathrm{III})$ concentration, the concentration of the reactants, $\mathrm{pH}$ and ionic strength were judiciously chosen from the kinetic examination of the catalytic electron transfer reaction [39]. The reaction conditions under which the catalytic activity of $\mathrm{Ru}(\mathrm{III})$ was optimum were selected for quantitative analysis. All the standard solutions were thermally equilibrated at $303.0 \pm 0.1 \mathrm{~K}$. The pseudo-first-order conditions were applied to study the reaction by taking minimum 10 times excess of periodate over hexacyanoferrate(II). The progress of the electron transfer of hexacyanoferrate(II) by periodate was monitored using "fixed time procedure" in highly alkaline medium by computing the increase in absorbance at $420 \mathrm{~nm}$. The change in absorbance at a definite time interval were computed to plot the calibration curve 
between $\mathrm{Ru}(\mathrm{III})$ concentration and change in absorbance. To prevent the complications arising due to possible interference by the reagents and products present in the reaction system, the inceptive rate was followed to determine $\mathrm{Ru}(\mathrm{III})$.

\section{Results and Discussion}

The optimum reaction condition has been established and fixed time procedure was adopted to obtain regression equations. The graphs plotted between $\Delta$ At (change in absorbance at $t$, min) versus $[\mathrm{Ru}(\mathrm{III})]$ (Fig.1) exhibited the linear dependency on $[\mathrm{Ru}(\mathrm{III})]$ in the concentration range of $(1-20) \cdot 10^{-7} \mathrm{M}\left(10-202 \mathrm{ng} \cdot \mathrm{ml}^{-1}\right)$, which is in good agreement with theoretical concept. The calibration equations relating $\Delta A t(t=2,5$ and $7 \mathrm{~min})$ and [Ru(III)], detection limit and correlation coefficients $\left(r^{2}\right)$, are summarized in Table 2.

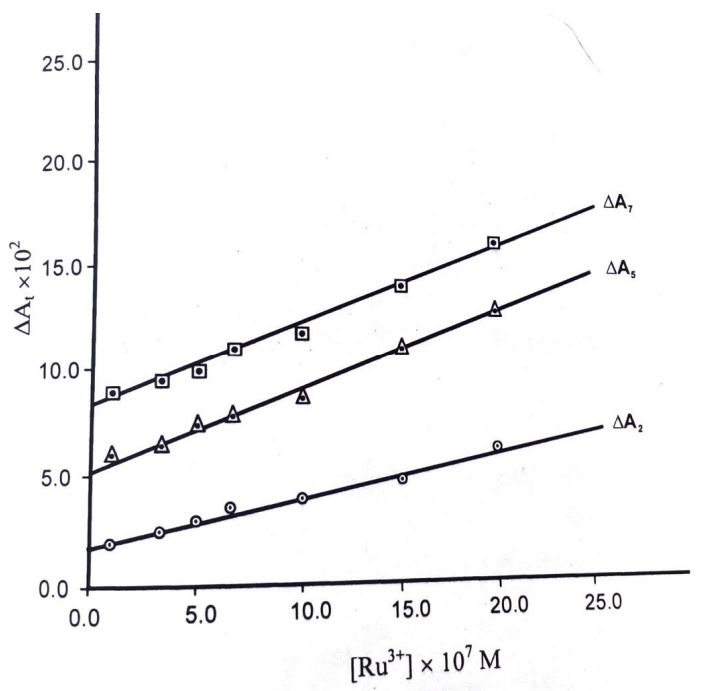

Fig. 1. Plot between $\Delta A t$

(change in absorbance at $t, \min ) v s .[\mathrm{Ru}(\mathrm{III})]$

Table 2

Determination of ruthenium(III)

at $\left[\mathrm{Fe}(\mathrm{CN})_{6}\right]^{4-}=2.25 \cdot 10^{-4},\left[\mathrm{NaIO}_{4}\right]=7.5 \cdot 10^{-3}, \mathrm{pH}=9.5 \pm 0.02, T=303 \pm 0.1 \mathrm{~K}, I=0.1 \mathrm{M}(\mathrm{NaCl})$

\begin{tabular}{|c|c|c|c|}
\hline Calibration equations & Linear range, $\mathrm{M}$ & Detection limit, $\mu \mathrm{g} \cdot \mathrm{ml}^{-1}$ & Correlation coefficient $r^{2}$ \\
\hline$\Delta A_{2}=2.25 \cdot 10^{4}\left[\mathrm{Ru}^{3+}\right]+0.018$ & $(1-20) \cdot 10^{-7}$ & 0.0081 & 0.9972 \\
\hline$\Delta A_{5}=3.28 \cdot 10^{4}\left[\mathrm{Ru}^{3+}\right]+0.053$ & $(1-20) \cdot 10^{-7}$ & 0.0053 & 0.9921 \\
\hline$\Delta A_{7}=4.31 \cdot 10^{4}\left[\mathrm{Ru}^{3+}\right]+0.078$ & $(1-20) \cdot 10^{-7}$ & 0.0038 & 0.9892 \\
\hline
\end{tabular}

Table 3

Computation of recovered ruthenium(III) in spiked water with \% error at $\left[\mathrm{Fe}(\mathrm{CN})_{6}\right]^{4-}=2.25 \cdot 10^{-4},\left[\mathrm{NaIO}_{4}\right]=7.5 \cdot 10^{-3}, \mathrm{pH}=9.5 \pm 0.02, T=303 \pm 0.1 \mathrm{~K}, I=0.1 \mathrm{M}(\mathrm{NaCl})$

\begin{tabular}{|c|c|c|c|c|c|c|}
\hline \multirow{2}{*}{$\mathrm{Ru}(\mathrm{III})$ taken, $\mathrm{ng} \cdot \mathrm{ml}^{-1}$} & \multicolumn{2}{|c|}{$\Delta A_{2}$} & \multicolumn{2}{c|}{$\Delta A_{5}$} & \multicolumn{2}{c|}{$\Delta A_{7}$} \\
\cline { 2 - 7 } & $\begin{array}{c}\mathrm{Ru}(\mathrm{III}) \text { found, } \\
\mathrm{ng} \cdot \mathrm{ml}^{-1} \pm \text { S.D. ng } \cdot \mathrm{ml}^{-1}\end{array}$ & Error, \% & $\begin{array}{c}\mathrm{Ru}(\mathrm{III}) \text { found, } \\
\mathrm{ng} \cdot \mathrm{ml}^{-1} \pm \text { S.D. } \mathrm{ng} \cdot \mathrm{ml}^{-1}\end{array}$ & Error, \% & $\begin{array}{c}\mathrm{Ru}(\mathrm{III}) \text { found, } \\
\mathrm{ng} \cdot \mathrm{ml}^{-1} \pm \text { S.D. } \mathrm{ng}^{-} \mathrm{ml}^{-1}\end{array}$ & Error, \% \\
\hline 10.11 & $10.08 \pm 0.09$ & -0.30 & $9.96 \pm 0.08$ & -1.51 & $9.91 \pm 0.10$ & -2.02 \\
\hline 33.35 & $33.66 \pm 0.13$ & 0.93 & $33.98 \pm 0.21$ & 1.85 & $33.82 \pm 0.18$ & 1.39 \\
\hline 50.54 & $51.02 \pm 0.28$ & 0.95 & $51.09 \pm 0.33$ & 1.08 & $51.11 \pm 0.62$ & 1.12 \\
\hline 67.72 & $66.98 \pm 0.46$ & -1.09 & $67.02 \pm 0.51$ & -1.04 & $66.82 \pm 0.88$ & -1.35 \\
\hline 101.07 & $102.13 \pm 0.39$ & 1.05 & $102.45 \pm 0.56$ & 1.35 & $102.82 \pm 0.76$ & 1.70 \\
\hline 121.28 & $119.96 \pm 0.53$ & -1.09 & $117.08 \pm 0.25$ & -3.59 & $118.06 \pm 0.44$ & -2.73 \\
\hline 151.601 & $153.24 \pm 0.76$ & 1.08 & $152.41 \pm 0.26$ & 0.53 & $154.21 \pm 0.32$ & 1.69 \\
\hline 181.93 & $181.06 \pm 0.65$ & -0.48 & $180.26 \pm 0.61$ & -0.93 & $180.06 \pm 0.68$ & -1.04 \\
\hline 202.14 & $200.86 \pm 0.23$ & -0.63 & $198.25 \pm 0.38$ & -1.96 & $199.61 \pm 0.21$ & -1.27 \\
\hline
\end{tabular}

The precision, accuracy and reproducibility of the present method for $\mathrm{Ru}(\mathrm{III})$ determination was tested by adding calculated amount of $\mathrm{Ru}(\mathrm{III})$ in double distilled water and conducting experiments for recovery. The percentage errors and standard deviation for the recovered ruthenium(III) concentration are given in Table 3. The error corresponding to regression equation $\Delta A_{2}$ is less than that of $\Delta A_{5}$ and $\Delta A_{7}$ (Table 3) because
$\Delta A_{2}$ is a close study of the initial rate than $\Delta A_{5}$ or $\Delta A_{7}$. Therefore, a fixed time interval of 2 min was preferred for further measurement, which shows a good agreement between short time of analysis and reproducibility. The results in Table 3 show excellent reproducibility of the proposed method. The regression equation $\Delta A_{2}$ is therefore advocated for trace level determination of $\mathrm{Ru}(\mathrm{III})$. 
Impact of various cations and anions on determination of $1.4 \cdot 10^{-7} \mathrm{M}\left[\mathrm{Ru}^{3+}\right]$ using $\Delta A_{2}$ calibration curve

$\left[\mathrm{Fe}(\mathrm{CN})_{6}\right]^{4-}=2.25 \cdot 10^{-4},\left[\mathrm{NaIO}_{4}\right]=7.5 \cdot 10^{-3}, \mathrm{pH}=9.5 \pm 0.02, T=303 \pm 0.1 \mathrm{~K}, I=0.1 \mathrm{M}(\mathrm{NaCl})$

\begin{tabular}{|c|c|c|}
\hline Foreign ions & Concentration taken, $\mathrm{M} \cdot 10^{5}$ & Tolerance level ([interfering ion]/ $\left[\mathrm{Ru}^{3+}\right]$ ) \\
\hline $\mathrm{Ca}^{2+}$ & 1.45 & 103.57 \\
\hline $\mathrm{Co}^{3+}$ & 1.75 & 125.00 \\
\hline $\mathrm{Ba}^{2+}$ & 1.25 & 89.29 \\
\hline $\mathrm{SCN}^{-}$ & 1.25 & 89.29 \\
\hline $\mathrm{S}_{2} \mathrm{O}_{3}^{--}$ & 1.6 & 114.29 \\
\hline $\mathrm{CH}_{3} \mathrm{COO}^{-}$ & 1 & 71.43 \\
\hline $\mathrm{Cl}^{-}$ & 1.75 & 125.00 \\
\hline $\mathrm{Br}^{-}$ & 1.3 & 92.86 \\
\hline $\mathrm{NO}_{3}^{-}$ & 1.4 & 100.00 \\
\hline $\mathrm{EDTA}^{-}$ & 0.20 & 14.29 \\
\hline $\mathrm{HEDTA}$ & 0.20 & 14.29 \\
\hline $\mathrm{IDA}$ & 0.20 & 14.29 \\
\hline
\end{tabular}

Table 5

Application of developed method in tap water samples using $\triangle \mathbf{A}_{2}$ calibration curve $\left[\mathrm{Fe}(\mathrm{CN})_{6}\right]^{4-}=2.25 \cdot 10^{-4},\left[\mathrm{NaIO}_{4}\right]=7.5 \cdot 10^{-3}, \mathrm{pH}=9.5 \pm 0.02, T=303 \pm 0.1 \mathrm{~K}, I=0.1 \mathrm{M}(\mathrm{NaCl})$

\begin{tabular}{|c|c|c|c|}
\hline Samples of tap water & {$\left[\mathrm{Ru}^{3+}\right]$ added, $\mathrm{ng}^{\prime} \mathrm{ml}^{-1}$} & {$\left[\mathrm{Ru}^{3+}\right]$ found, $\mathrm{ng} \cdot \mathrm{ml} l^{-1}$} & Recovery, \% \\
\hline Sample 1 & 10.33 & 10.51 & 101.74 \\
\hline Sample 2 & 12.84 & 13.28 & 103.43 \\
\hline Sample 3 & 16.54 & 17.02 & 102.90 \\
\hline
\end{tabular}

\subsection{Study of Interferences (Sensitivity)}

The sensitivity of the proposed method was studied under optimum reaction condition by addition of various cations, anions and poly-aminocarboxylates to fixed ruthenium(III) concentration $\left(1.5 \cdot 10^{-7} \mathrm{M}\right)$. The tolerance limit of the added ions was considered not more than $\pm 5 \%$ relative error. The results (Table 4 ) reveals that the catalytic activity of $\mathrm{Ru}(\mathrm{III})$ was not significantly affected by most common ions up to 71 times higher concentration. Polyaminocarboxylates (HEDTA, EDTA and IDA) containing free amino and carboxylic groups form strong co-ordinate complexes with $\mathrm{Ru}(\mathrm{III})$, which suppress its catalytic power to maximum, if tolerance limit is more than 14.29 times.

\subsection{Analytical Application of Developed Method}

To test the applicability and reliability, the proposed method was applied to determine the $[\mathrm{Ru}(\mathrm{III})]$ in three different samples of tap water having $\mathrm{Ru}(\mathrm{III})$ concentration in increasing order.

Because of very low content of $\mathrm{Ru}(\mathrm{III})$ in tap water it was added to the water samples so that the concentration of $\mathrm{Ru}(\mathrm{III})$ will be in detection range of proposed method (Table 3). The recovery results in Table 5 indicates the quantitative and higher recovery of $\mathrm{Ru}(\mathrm{III})$ in every case, which may be due to the synergistic effect of other cations present in tap water. Thus, the developed method can be effectively used for the quantitative determination of ruthenium(III) in mixtures of several metal ions in comparatively higher concentration (Table 3).

\section{Conclusions}

The experimental data confirms the reproducibility, stability and selectivity of the developed method to determine $\mathrm{Ru}(\mathrm{III})$ quantitatively in different types of water samples using readily available and inexpensive reagents. The proposed catalytic spectrophotometric method has good sensitivity with low detection limit as compared to other developed CKM-SPM. In most of other methods, substrates used are expensive and rarely available while other few used quencher and activator for analysis. Over all, the developed method can be effectively applied for the trace level ruthenium(III) analysis in tap water.

\section{References}

[1] Balcerzak M.: Rev. Anal. Chem., 2002, 32, 181. https://doi.org/10.1080/10408340290765524

[2] Druskovic V., Vojkovic V., Jelic T.: Croatica Chem. Acta, 2005, 78, 617. 
[3] Berggren K., Steinberg T., Lauber W. et al.: Anal. Biochem., 1999, 276, 129. https://doi.org/10.1006/abio.1999.4364

[4] Lindino C., Bulhoes L.: J. Braz. Chem. Soc., 2004, 15, 178. https://doi.org/10.1590/S0103-50532004000200004

[5] Alarfa N., El-Razeq S.: J. Pharm. Biomed. Anal., 2006, 41, 1423. https://doi.org/10.1016/j.jpba.2006.03.011

[6] Zhou Z., Zhang I.: Adv. Mater. Res., 2013, 602-604, 1289. https://doi.org/10.4028/www.scientific.net/AMR.602-604.1289 [7] Zhou Z., Zhang I.: Appl. Mechanics Mater., 2012, 217-219, 2397. https://doi.org/10.4028/www.scientific.net/AMM.217219.2397

[8] Byadagi K., Nandibewoor S., Chimatadar S.: Acta Chim. Slov., 2013, 60, 617.

[9] Sharanabasamma K., Angadi A., Tuwar S.: The Open Catal. J., 2011, 4, 1. https://doi.org/10.2174/1876214X01104010001

[10] Keyvanfard M.: World Acad. Sci. Eng. Tech. 2008, 43.

[11] Hosamani R., Nandibewoor S.: J. Chem. Sci., 2009, 121, 275. https://doi.org/10.1007/s 12039-009-0030-y

[12] Srivastava S., Chaudhary L., Singh K.: Int. J. Res. in Phys. Chem., 2012, 2, 6.

[13] Babasaheb D., Bhosale A., Gokavib G.: Adv. Appl. Sci. Res. 2012, 3, 785.

[14] Mishra K., Chaturvedi R., Shukla M.: Ind. J. Chem. 2010, 49A, 185.

[15] Kumar A., Reddy P., Reddy V.: Int. J. ChemTech. Res., 2013, 5,1442 .

[16] Ritika M., Barhate V.: Int. J. ChemTech. Res., 2013, 5, 1578.

[17] Sateesh B., Shastry V., Shashidhar S., Manoj K.: Int. J. Chem. Sci., 2014, 14, 1109.

[18] Fawaz A.: J. Chem. Sci., 2016, 128, 733.

https://doi.org/10.1007/s12039-016-1067-3

[19] Gorakh S., Antonio D., Jyoti G. et al.: Chem. Commun., 2013, 49, 11533. https://doi.org/10.1039/c3cc46239k

[20] Lakomska I., Fandzloch M., Muziol T. et al.: Dalton Trans., 2013, 42, 6219. https://doi.org/10.1039/c2dt32216a

[21] Sharma A., Gangrade, Bakshi D., John J.: Int. J. ChemTech. Res., 2014, 4, 828.

[22] Schoekel A., Melke J., Burns M. et al.: J. Power Sources, 2016, 301, 210. https://doi.org/10.1016/j.jpowsour.2015.09.119

[23] Hsieh Y., Zang Y., Su D. et al.: Nat. Commun., 2013, 2466. https://doi.org/10.1038/ncomms3466

[24] Messori L., Camarri M., Ferraro T. et al.: A.C.S. Med. Chem. Lett., 2013, 4, 1124. https://doi.org/10.1021/ml400390c

[25] Brunken S., Kratzig A., Bogdanoff P. et al.: Thin Solid Films, 2013, 527, 16. https://doi.org/10.1016/j.tsf.2012.12.037

[26] Madan P., Barhate V.: Int. J. Sci. Res., 2016, 5, 778.

[27] Shelar S., Bhor R., Anuse M., Naval R.: Sep. Sci. Tech., 2015, 50, 1190. https://doi.org/10.1080/01496395.2014.983245

[28] Prasad S., Naik R., Srivastava A.: Spectrochim. Acta A, 2008, 69, 193. https://doi.org/10.1016/j.saa.2007.03.030
[29] Naik R., Srivastava A., Prasad S.: Spectrochim. Acta A, 2008, 70, 958. https://doi.org/10.1016/j.saa.2007.10.011

[30] Zhou Z., Zhang L.: Appl. Mech. Mater., 2012, 204-208, 4067. [31] Sreekanth B., Jonnalagadda, Brijesh P.: Anal. Lett., 2011, 1868 .

[32] Jonnalagadda S., Chinake C., Love I.: Fresenius Anal. Chem., 1994, 349, 829. https://doi.org/10.1007/BF00323114

[33] Keyvanfard M., Rezaei B.: Can. J. Anal. Sci. Spectrosc., 2005, $\mathbf{5 0}, 221$.

[34] Crouch S., Scheeline A., Kirkor E.: Anal. Chem., 2000, 72, 53. https://doi.org/10.1021/a1000004b

[35] Prasad S.: Asian J. Chem., 2002, 14, 799.

[36] Prasad K., Rao N.: React. Kinet. Catal. Lett., 1995, 56, 273. https://doi.org/10.1007/BF02076032

[37] Khayamian T., Ensafi A., Atabati M.: Anal. Lett., 2002, 35, 2039. https://doi.org/10.1081/AL-120014292

[38] Bhagwat V., Vijay R., Jonnalagadda S., Pare B.: Indian J. Chem. Technol., 2006, 13, 644.

[39] Naik R., Srivastava A., Asthana A.: J. Iran. Chem. Soc., 2008, 5, 29. https://doi.org/10.1007/BF03245812

Received: February 05, 2018 / Revised March 23, 2018 / Accepted: July 12, 2018

\section{СПЕКТРОФОТОМЕТРИЧНЕ ВИЗНАЧЕННЯ РУТЕНІЮ 3 ВИКОРИСТАННЯМ ЙОГО КАТАЛІТИЧНОЇ АКТИВНОСТІ НА ОКИСНЕННЯ ГЕКСАЦИАНОФЕРРАТА(II) ПЕРІОДАТНИМ ЙОНОМ В ЗРАЗКАХ ВОДИ}

\begin{abstract}
Анотація. Для визначення рутенію(III) на мікрорівні застосовано каталітичний ефект хлориду рутенію на зовнішнє перенесення електронів гексаціаноферрату(II) періодатним йоном у водному лужному середовищі. Встановлено оптимальні умови реакиії та необхіднй час. Лінійна залежність між поглинальною здатністю та кониентрацією $R u(I I I)$ використана для визначення слідів Ru(III). Показано, щзо додавання інтерферентних йонів (в конщентраціях, до 71 разів вищих за концентрачію $R u$ ) істотно не впливає на каталітичну активність Ru(III) при окисненні гексачіаноферрату(II) періодатним йоном. Поліамінокарбоксилати пригнічують його каталітичну здатність до максимального значення, якщо допустима межа є більшою за 14,29. Враховуючи відтворюваність, стабільність та селективность изьго методу, запропоновано використовувати його для різних типів зразків води для визначення рутенію(III) на мікрорівні.
\end{abstract}

Ключові слова: кінетика, механізм, гексаціаноферрат(II), періодат, рутеній(III). 